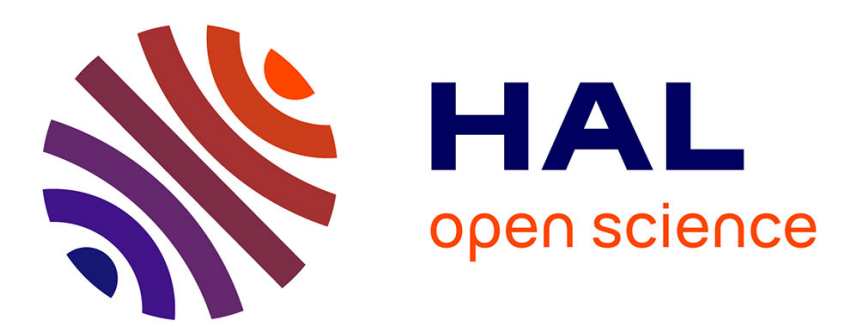

\title{
The politics of forest governance failure in the Democratic Republic of Congo (DRC): lessons from 35 years of political rivalries
}

Eliezer Majambu, Moise Tsayem Demaze, Symphorien Ongolo

\section{- To cite this version:}

Eliezer Majambu, Moise Tsayem Demaze, Symphorien Ongolo. The politics of forest governance failure in the Democratic Republic of Congo (DRC): lessons from 35 years of political rivalries. International Forestry Review, 2021. halshs-03503672

\section{HAL Id: halshs-03503672 \\ https://shs.hal.science/halshs-03503672}

Submitted on 3 Jan 2022

HAL is a multi-disciplinary open access archive for the deposit and dissemination of scientific research documents, whether they are published or not. The documents may come from teaching and research institutions in France or abroad, or from public or private research centers.
L'archive ouverte pluridisciplinaire HAL, est destinée au dépôt et à la diffusion de documents scientifiques de niveau recherche, publiés ou non, émanant des établissements d'enseignement et de recherche français ou étrangers, des laboratoires publics ou privés. 


\title{
The politics of forest governance failure in the Democratic Republic of Congo (DRC): lessons from 35 years of political rivalries
}

\author{
E. MAJAMBU ${ }^{a, b}$, M. TSAYEM DEMAZE ${ }^{a}$ and S. ONGOLO ${ }^{c, d}$ \\ ${ }^{a}$ Department of Geography, Le Mans University-France-UMR CNRS 6590 Espaces et Sociétés (ESO Le Mans) \\ ${ }^{b}$ Department of Political Science, Official University of Mbujimayi, Democratic Republic of Congo (DRC) \\ 'IRD - SENS, University of Montpellier Paul-Valéry 3, Montpellier, France \\ ${ }^{d}$ Chair of Forest and Nature Conservation Policy, University of Göttingen, Germany
}

Email: Eliezer.Majambu@univ-lemans.fr, Moise.Tsayem_Demaze@univ-lemans.fr, Symphorien.ongolo@ird.fr

\section{HIGHLIGHTS}

- Forest governance reforms in DRC have been dominated by the interests of powerful actors, such as the World Bank and political elites.

- The most powerful international actors use incentives/disincentives and information to consolidate their influence.

- Powerful international actors have exacerbated the crisis of forest governance in DRC.

- Politicians, military and administrative officers in DRC resort to 'cunning government' strategies to obtain support from donors or assert their informal interests in times of political unrest.

- The context of political disorder allows civil society organizations to position themselves and become one of the key actor groups of forest governance processes in DRC.

\section{SUMMARY}

The promotion of good governance in the forestry sector in the Democratic Republic of Congo (DRC) was one of the major components of the policy reforms initiated by international organisations in the mid-1980s. This paper analyses concepts of 'good governance' in the forestry sector in the DRC between the mid-1980s and 2020 and highlights the recent history of forest policy reforms. From an empirical perspective, our analysis builds both on an extensive review of policy documents and field observations, as well as interviews with actors who have been involved with forest policy reforms or seen how they were implemented. The paper also describes the key actors involved in those reforms and investigates the coalitions formed between some of them to influence the forestland governance in the country. The paper demonstrates that international organisations have often played a decisive and intrusive role in the promotion of 'good governance' in the DRC forestry sector. Their strong involvement is sometimes seen as interference and has aggravated rather than alleviated the governance crisis. In some cases, politicians, military and administrative officers have used political and security unrest as a scapegoat to benefit from forest governance failure and the related business-as-usual in the DRC.

Keywords: forest governance, power, African politics, forest policy reform, Democratic Republic of Congo

\section{Politique de l'échec dans la gouvernance des forêts en République Démocratique du Congo (RDC): leçons de 35 ans de rivalités politiques}

\section{E. MAJAMBU, M. TSAYEM DEMAZE et S. ONGOLO}

La promotion de la bonne gouvernance dans le secteur forestier a été l'une des composantes majeures des réformes politiques initiées par les organisations internationales depuis le milieu des années 1980 en République démocratique du Congo (RDC). Cet article analyse les rivalités politiques liées à cet agenda de réformes pour la "bonne gouvernance" dans le secteur forestier en RDC pour la période entre 1980 et 2020. D'un point de vue empirique, notre analyse s'appuie à la fois sur un examen approfondi des documents de politiques publiques et des observations de terrain conduites dans diverses arènes de gouvernance à l'échelle nationale et locale. Les données mobilisées sont confrontées et complétées par des entretiens conduits auprès des acteurs clés impliqués dans la formulation ou la mise en œuvre des réformes de politiques forestières. A cet effet, l'article propose une cartographie précise des principaux acteurs de la gouvernance des forêts en RDC, ainsi qu'une analyse détaillée des intérêts et coalitions desdits acteurs. Cet article démontre notamment que les organisations internationales ont souvent joué un rôle décisif et intrusif dans le secteur forestier de la RDC pour la promotion de la "bonne gouvernance". Leur forte implication est souvent perçue comme une ingérence et contribue à aggraver les crises de gouvernance des forêts en RDC au lieu d'en atténuer les effets. Dans certains cas, certains acteurs et élites nationaux et provinciaux (politiciens, militaires et hauts fonctionnaires) instrumentalisent les crises politiques et sécuritaires récurrentes comme bouc-émissaires associés aux ingérences étrangères, pour profiter du désordre systémique et du statuquo qui règnent dans la gouvernance des forêts en RDC. 


\title{
La política del fracaso de la gobernanza forestal en la República Democrática del Congo (RDC): lecciones de 35 años de rivalidades políticas
}

\author{
E. MAJAMBU, M. TSAYEM DEMAZE y S. ONGOLO
}

El fomento de la buena gobernanza en el sector forestal de la República Democrática del Congo (RDC) fue uno de los componentes principales de las reformas políticas iniciadas por las organizaciones internacionales a mediados de la década de 1980. Este artículo analiza las rivalidades para establecer esa 'buena gobernanza' en el sector forestal de la RDC entre mediados de la década de 1980 y 2020 y destaca la historia reciente de las reformas de la política forestal. Desde un punto de vista empírico, este análisis se basa tanto en una amplia revisión de documentos sobre políticas y en observaciones de campo, como en entrevistas con las personas que han participado en las reformas de la política forestal o que han observado cómo se aplicaban. El artículo también describe los principales actores implicados en esas reformas e investiga algunas de las coaliciones formadas entre algunos de ellos para influir en la gobernanza de los bosques en el país. El artículo demuestra que las organizaciones internacionales han desempeñado a menudo un papel decisivo e intrusivo en la promoción de la 'buena gobernanza' en el sector forestal de la RDC. Su fuerte involucramiento se ve a veces como una interferencia que ha agravado la crisis de gobernanza, en lugar de aliviarla. En algunos casos, los políticos, el ejercito y los funcionarios de la administración han utilizado los disturbios políticos y de seguridad como chivo expiatorio para beneficiarse del fracaso de la gobernanza forestal y del statu quo relacionado con ella en la RDC.

\section{INTRODUCTION}

Attempts to apply 'good governance' to the forestry sector in Congo Basin countries, including in the Democratic Republic of Congo (DRC), have resulted in an array of institutional and bureaucratic reforms since the mid-1990s (Hoogeveen and Verkooijen 2010, Ehrenstein 2013, Dkamela et al. 2014, Viard-crétat 2015). In some cases, these reforms were used to legitimize or justify the interventions of several international actors, both from the public and the private sector (Doherty and Schroeder 2011, Aquino and Guay 2013, Ochieng et al. 2016). In this regard, the contribution of sustainable forest management standards and international instruments to curbing deforestation is often presented as a motive for forest policy reforms. But for some analysts, the more or less subtle imposition of these reforms and the related norms and policy instruments often contribute to perpetuating the interventionism of international actors in forest governance in the Congo Basin (Dkamela et al. 2014, Karsenty 2017, Tsayem et al. 2020).

In Congo basin countries, attempts to reform forestry policies are often perceived by domestic actors as imposed policy measures promoted by international actors (Sharpe 1998, Ekoko 2000, Oyono 2004, Karsenty 2017). In the DRC, recurrent cycles of such endeavours have often been justified by referring to the shortcomings of a quasi-failed state (Trefon 2009, Kabamba 2010), deemed unable to guarantee fair and sustainable forestland management (Debroux et al. 2007, Burnley 2011, Lawson 2014). Numerous studies highlight the challenges (corruption, conflicts, illegal logging, participation bias, etc.) that undermine the implementation of a 'good' governance in the forestry sector. However, the analysis of power relations between international and national actors in favour of or against forest policy reforms in the country remains marginal. In addition, little is known about the coalition dynamics among key actors involved in forest governance and related reforms, be they coalitions for the defence of various formal and informal interests, or coalitions in favour of a business-as- usual for actors who benefit from the countries' persistent forest governance crisis. By combining the conceptual and an empirical approach, we hope to narrow the knowledge gap.

Previous studies investigated the interventions of major international organisations, including the World Bank (WB), in national forestry policy in Central Africa (Seymour et al. 2000, Ekoko 2000, Ehrenstein 2013, Dkamela et al. 2014, Karsenty 2017). In some cases (Ongolo and Karsenty 2015), such interventions contributed to strengthening the aversion of recipient governments to the initiatives of international actors. Furthermore, these external interventions were used to consolidate the exploitation of institutional weaknesses of the recipient countries' bureaucratic systems. Building on the aforementioned studies and the work of Bernstein and Cashore (2012), the key hypothesis guiding this research is that a group of international organisations and transnational conservation NGOs that are involved in forestland governance exercise pressure on recipient actors through various forms of power strategies which aim at imposing 'good' governance in the forestry sector in the DRC. Their influence can be either autonomous or through the formation of sporadic coalitions with other groups of actors (Sabatier 1999).

The domination capacity of these actors depends on two major strategies that align with the categorisation developed by Krott et al. (2014). First, incentive-based strategies (conditionality of international aid, intermittent and targeted allocations of international funding in the form of projects, promises of support, etc.), second, a power strategy based on domination through information ('blame and shame' campaigns, oriented policy reforms rooted in external expertise, etc.). This paper analyses attempts to establish 'good' governance in the forestry sector in DRC from the mid-1980s to 2020 .

The notion of 'good' governance that this paper refers to appeared for the first time in international development agenda in the late 1980s, notably through the World Bank's report entitled Sub-Saharan Africa: From Crisis to Sustainable Growth - A Long Term Perspective Study (Elahi 2009, 
Gisselquist 2012, Santiso 2014). According to the aforementioned report, structural adjustment (economic austerity policies) programmes launched by the international financial institutions including the World Bank have failed to bring economic growth because of the 'crisis of governance' that characterizes most developing countries (World Bank 1989). In developing countries, the World Bank employs the concept of governance in two slightly different ways. First, the World Bank emphasised how political power is exercised to manage a country's affairs. Second, political power is perceived as the "use of power in the management of a country's socioeconomic development-oriented resources" (Khan quoted by Ali 2019:67). Governance becomes 'good' when the decisions and actions of actors in any sector, in this case, the forestry sector, are based on transparency, accountability and the people's consent (Ali 2019). As such, 'good governance' was introduced by the World Bank (WB) and the International Monetary Funds (IMF) as an additional prerequisite for loans for development projects (Grindle 2010, Katsamunska 2016, Keping 2018). In this context, 'good' governance refers to a set of public administrative or bureaucratic processes aimed at maximizing work done in the public interest (Keping 2018) and thus is supposed to be a solution to governance failures, and to inefficient and corrupt administrative structures, especially in developing countries (Nanda 2006, Santiso 2014). But the limits to the notion of 'good' governance change and evolve and thus remain uncertain. The meaning of 'good' governance largely depends on aims and context (Osmont 1998, Gisselquist 2012, Santiso 2014, Lateef 2016).

During the 1980s, the World Bank and the IMF for instance tended to emphasise economic reforms, while the more political organisations included human rights law in the concept of 'good' governance (de la Harpe et al. 2008). However, since the 1990s, the World Bank has focused on both aspects because the 'good' governance agenda has been perceived as a crucial element in state building (Doornbos 2006, Ali 2019). To assess the level of performance of 'good' governance in any sector in developing countries, the World Bank and other multilateral organisations which promote this notion uses a range of associated indicators such as accountability, transparency, rule of law, participation, responsiveness, effectiveness, fairness, etc. (Plumptre and Graham 1999, World Bank 1994, de la Harpe et al. 2008, Elahi 2009).

After this introduction, the following sections include the conceptual and theoretical framework, methodology, results, discussion and conclusion.

\section{CONCEPTUAL AND THEORETICAL FRAMEWORK}

This research aims at identifying and explaining the actors' interests and power strategies that governed the forest sector in DRC from the mid-1980s to 2020. To do this, the conceptual and theoretical framework of this study includes the development of four analytical components: (i) actors' identification and related roles, (ii) actors' power, (iii) actors' interests (iv), and the effects of actors' coalitions on the politics of forest governance reforms.

\section{Actors' identification and related roles}

The forest governance reforms processes were initiated in the DRC by a group of actors with different agendas and interests. This explains why the notion of actor is one of the main analytical components of this study. The works of Crozier and Friedberg (1977), and Schusser et al. (2016) are particularly insightful for a thorough and contextualised understanding of this notion. According to Crozier and Friedberg (1977) from a conceptual perspective, an actor is an autonomous entity who use her/his power to control the uncertainties of its partners' actions.

Although this definition suggested by Crozier and Friedberg (1977) applies to the sociology of organisations, it explains the conditions that could favour constrain or curtail the capacity of an actor to act in a given environment. Schusser et al. (2016) gave a definition stemming from empirical studies specifically regarding the context of forest policies. According to these authors, the notion of actor refers to 'any entity that has a distinct interest and the ability to influence a policy'. In our research, there is a plethora of key public and private actors involved in forest policy and governance reforms in the DRC, they often played a decisive role in the transformation of forestland governance. Those actors include international financial organisations (World Bank and International Monetary Fund), non-governmental conservation organisations such as the (IUCN) International Union for Conservation of Nature, (WWF) the World Wildlife Fund, Greenpeace, Rainforest Foundation, etc., bilateral technical cooperation agencies, including AFD (Agence Française de Développement), KfW (German development Bank), BTC (Belgian technical cooperation), NORAD (Norwegian Agency for Development Cooperation), GIZ (German technical cooperation) and USAID (US Agency for International development-) cooperation. Some United Nations multilateral agencies (FAO, UNDP, UNEP) that have been involved in forestland governance in the DRC often collaborate with domestic actors such as State bureaucracies, industrial timber federation (ITF) and civil society organisations including local associations. Each of these categories of actors has a greater or lesser significant influence on forestland governance.

\section{Actors' Power}

According to Foucault (1978), the concept of power refers to the capacity of a disciplining authority to change the behaviour of people without any apparent physical coercion. This definition does not consider physical coercion as the main element of power. The relevance of this definition differentiates Michel Foucault's perception of power with the one suggested by Weber (1978). The latter defines power as the capacity of getting an actor to do something which he/she would have potentially never agreed to do. Power can be exercised through a network of organisations which are made up of actors who allow power to move around in the organisations (Gordon 1980). With this in mind, the way to analyse power is to 'examine the stakeholder's resources and instruments' (Etzioni 1975:333). 
According to Krott et al. (2014), these resources and instruments constitute the core elements of power and refer to coercion, (dis)incentives, and dominant information. Firstly, the authors define coercion as the fact of 'altering behaviour with force', which includes the threat of force and even the bluffing about force that does not exist. Secondly, they argue that (dis)incentives refer to the possibility of "implementing advantages or disadvantages until the subordinate changes his/her behaviour in the direction of the goals of the potentate" (Krott et al. 2014:6). The advantage in this case can be financial support, and the disadvantage can be related to the sanctions or 'blame and shame' campaign. Finally, dominant information refers to the capacity to 'alter behaviour of the subordinate by means of unverified information'. Krott et al. (2014:6) argue that "not checking information can be voluntary or compulsory. It is voluntary if the subordinate is guided by his confidence in the potentate's good will."

Those various elements of power are often mobilised by actors with the ultimate goal to satisfy their formal and/or informal interests.

\section{Actors' Interests}

McMillan dictionary ${ }^{1}$ defines interest as "a connection with something that influences your attitude or behaviour because you can gain an advantage from it". In the specific case of the forest policy domain, Krott (2005:8) argues that "the interests are based on action orientation, adhered to by individuals or groups, and they designate the benefits the individual or group can receive from a certain object, such as forest". These interests (economic, political or strategic) may be formal or informal as pointed out by Rahman and Giessen (2017). Other works have shown that guaranteeing informal interests was fundamental for some organisations with 'sensitive' areas of activity because a substantial part of strategic resources that enable organisations to keep a certain level of influence and expansion come from the informal sector (Betsill and Corelle 2001, Renaud 1995, Schoener 1997). To secure their interests, actors can resort to coalitions.

\section{Actors' Coalitions}

A coalition group or union is defined as a set of individuals or entities of various professions (politicians, bureaucrats, interest group leaders, scientists, etc.) who share a particular concern, value or belief system, with a recognizable ability to coordinate their interests overtime (Sabatier 1987). This author identifies two main sets of coalitions that can influence public policy reform. The first set comprises external actors and the second comprises actors who are part of the political system (Sabatier 1999; 1987). Changes in domestic policies result from the more or less conflicting interactions between these two groups. In many cases, these groups pursue divergent formal and informal interests (Mintrom and Vergari 1996, Bernstein and Cashore 2012, Burns et al. 2017).

In forest policy, the challenge of reconciling interests between groups of key external actors (international organisations and allies) and domestic actors (State bureaucracies, political-administrative elites and allies) is often at the root of the persistent crisis in the DRC's forest governance system. We used the Advocacy Coalition Framework, ACF (Sabatier 1999 1987) as a component of our analytical framework to explain the major changes or policy inertia that occurred in forest policies in the DRC during the last three decades.

\section{METHODOLOGY}

\section{Case study context}

With an estimated 107.2 $\mathrm{M}$ hectares at the beginning of the 2010s (Mayaux et al. 2013), DRC's primary forests are the largest tropical forests in Africa. They cover around twothirds of Congo's national territory (RDC-MECNT 2014) and constitute about $47 \%$ of the Congo Forest Basin (Marquant et al. 2015).

In the DRC, forests are divided into several categories: classified, permanent production and protected forests (Code forestier 2002).

The 'classified' category comprises protected areas (PA). Some PAs (Virunga Park, Salonga Park, Garamba Park and Okapi Wildlife Reserve), are supported financially and materially by DRC's external partners while others exist only on paper and have no management documents (IUCN 2010, Mampeta Wabasa 2017, Majambu et al. 2020).

The 'permanent production' category comprises forestlands that covered about 12 million hectares in 2020, a little less than $10 \%$ of DRC's forests ${ }^{2}$ according to official estimates. In July 2020, production forests were divided into 59 forest concessions, mainly located in 5 provinces $(71 \%)$ (Tshopo, Mai-Ndombe, Equateur, Mongala and Tshuapa) ${ }^{3,4}$.

The 'protected forests' category are part of private State property, the State alone decides on their use. This category includes 71 forests $^{5}$ (about one million hectares) that the State granted to local populations between 2017 and 2019 as community forests.

\footnotetext{
1 https://www.macmillandictionary.com/dictionary/british/interest_1 consulted on 26 September 2020

2 https://www.observatoire-comifac.net/monitoring_system/concessions consulted on 26 August 2020

3 https://archive.pfbc-cbfp.org/actualites/items/Atibt-bois.html consulted on 26 August 2020

${ }^{4}$ We were granted access to the report being prepared by the World Resources Institute (WRI) and the DRC Ministry of Environment. The report examines the forest management process in the DRC for the year 2020.

5 rdc.geocfcl.org
} 


\section{Empirical methods}

The State, and the international and national organisations play a crucial role in the governance of forestlands in the DRC. In order to provide a comprehensive analysis of their interventions in forest policy reforms, we studied several policy documents and reports produced by public and private national and international organisations which played an important role in the formulation and setting the agenda of forest policy reforms in the DRC since the mid-1980s (Table 1).

Since our data were mainly qualitative, we built our analysis on (i) a content analysis approach of policy documents collected (Table 1) during the study; (ii) while all interviews and interviewees were coded (Table 2) prior to a discursive analysis of the related content, and (iii) then we employed the key categories of our conceptual and theoretical framework for an in-depth analysis of the power dimensions influencing actors' interests through four fundamental power elements including coercion, incentive/disincentive, dominant information and coalition.

By applying desk research, the information drawn from the DRC's forestry sector policy documents and reports, allowed us to validate the statements made by some key interviewees. The first phase of remote interviews (6) was carried out between early April and late August 2020 mainly using video tools (Skype and WhatsApp) supplemented by inperson interviews (14) conducted in Kinshasa from end September 2020 to end March 2021. A summary of these interviews is presented in Table 2.

More formal interviews were recorded and rounded out by informal in-person conversations in Kisangani and Kinshasa (DRC) between April 2018 and November 2019. We also used field observation and information from workshops and conferences on forest governance in the DRC during the aforementioned period in this paper.

\section{RESULTS}

\section{Role and interests of international organisations under the Mobutu regime}

One of the major interests of international organisations in the DRC has been to 'reorganise' the forestry sector. In 1984, some international organisations, including IUCN and the Canadian International Development Agency (CIDA), with funding from the World Bank, organised a symposium on the Congolese forestry sector entitled Forest: a national wealth to preserve. The symposium drafted specific recommendations on combating deforestation, which was identified as the main cause of biodiversity loss (Trouvé 1995). The recommendations convinced the World Bank to make a thorough diagnosis of the Congolese forestry sector. The World Bank drew on the expertise of the International Institute for Environment and Development, IIED (PAFT-RDC 1989, Trouvé 1995). The output enabled the ministry in charge of the DRC forestry sector, with the assistance of CIDA, to develop a national forest action plan (PAFN) that was designed and formulated as a component of a wider programme, the Tropical Forest Action Plan, (PAFT) (FAO 2003, Trouvé 1995).

The DRC (called Zaïre from 1971 to 1997) PAFT was adopted by the government in 1990 during a round table of donors in Kinshasa. It focused on activities such as biodiversity conservation and sustainable forest management (PAFT-RDC 1989, Trouvé 1995).

In terms of participation, one of the plan's novelties was the recommendation to involve 'local communities' in the planning and implementation of rural development projects (Doumenge 1990,Trouvé 1995). The aim was to ensure that these communities had direct access to forestlands and related benefits while encouraging them to reinvest part of these benefits in sustainable forest management (PAFT-RDC 1989).

These policy measures in favour of local communities were intended to respond to criticism and pressure from international conservation NGOs with regard to the non-inclusive and authoritarian pattern of forest policies that prevailed in the DRC before the development of the PAFT. Despite this, NGOs have continued to criticise the PAFT for being too centralised, neglecting local issues and over-representing the private sector in relation to NGOs. Moreover, this is one of the reasons for the disassociation of conservation NGOs from the PAFT (Viard-crétat 2015).

Of the many actions planned in DRC's PAFT only the ones concerning protected areas and reforestation were carefully carried out (FAO 2003, Table 2, CCS-20200624). The major reasons often cited for the failure of forest policy reforms were institutional weaknesses and inefficient bureaucracy. Another reason was the sudden interruption of support from the international organisations following a massive popular uprising that led to the collapse of the political legitimacy of Mobutu's regime ${ }^{6}$ in the mid-1990s and the exacerbated political instabilities during the last few years of his rule (Clément 1994, Winterbottom 1990, RDC-PNFoCo 2003). Some authors such as Winterbottom (1990) pointed out that instead of promoting local community participation, PAFT had contributed to the discrimination against local populations and indigenous people including pygmies.

Officially, the international organisations abruptly withdrew from the Congolese forestry sector in the mid-1990s to express their solidarity with the Congolese population in denouncing the 'bad' governance of the Mobutu regime. However, some experts pointed out that the international community wanted to stoke a popular uprising against the Mobutu regime to further weaken it and force the president to resign (Table 2, R20200427, CCS20201015). A number of Congolese civil society organisations and international organisations which were particularly active in the DRC created a

${ }^{6}$ President Mobutu Sese Seko Kuku Ngbendu wa Za Banga ruled DRC (former Zaïre) from November 1965 to May 1997 under an authoritarian regime. 
TABLE 1 List of key policy documents analysed

\begin{tabular}{|c|c|c|c|}
\hline Title & Type & Institutional author & $\begin{array}{c}\text { Year of } \\
\text { publication }\end{array}$ \\
\hline DRC (Zaïre) Forest Action Plan & Programme document & African Development Bank & 1989 \\
\hline The Conservation of Zaire's Ecosystems & Report & IUCN & 1990 \\
\hline A strategy for the forest sector in sub-Saharan Africa & Technical report & World Bank & 1994 \\
\hline Forest policies in francophone Sub-Saharan Africa & Mission report & $\begin{array}{l}\text { José Trouvé (United Nations } \\
\text { Research Institute for Social } \\
\text { Development }\end{array}$ & 1995 \\
\hline Law n ${ }^{\circ} 011 / 2002$ of 29 August on DRC's Forest Code & Forest Code & Government of DRC & 2002 \\
\hline Assessing DRC's forest genetic resources & Report & FAO & 2003 \\
\hline Priority Agenda for the recovery of the forest sector & Priority Agenda & $\begin{array}{l}\text { DRC- ministry of the environment, } \\
\text { conservation of nature and } \\
\text { sustainable development }\end{array}$ & 2003 \\
\hline National Forest and Conservation Plan & National plan & $\begin{array}{l}\text { DRC- ministry of the environment, } \\
\text { conservation of nature and } \\
\text { sustainable development }\end{array}$ & 2003 \\
\hline $\begin{array}{l}\text { Ministerial Order } \mathrm{N}^{\circ} 050 / \mathrm{CAB} / \mathrm{MIN} / \mathrm{ECN}-\mathrm{EF} / 2004 \text { of } \\
\text { 2. July } 2004 \text { laying down the terms and conditions for } \\
\text { converting agreements granting timber supply } \\
\text { guarantees and letters of intent into forest concession } \\
\text { contracts }\end{array}$ & Ministerial Order & $\begin{array}{l}\text { DRC-ministry of the environment, } \\
\text { conservation of nature and } \\
\text { sustainable development }\end{array}$ & 2004 \\
\hline $\begin{array}{l}\text { Ministerial Order } n^{\circ} 071 / \mathrm{CAB} / \mathrm{MIN} / \mathrm{ECN}-\mathrm{AE} / 2004 \text { of } \\
22 . \text { November } 2004 \text { amending Order } n^{\circ} 050 / \mathrm{CAB} / \mathrm{MIN} / \\
\mathrm{ECN}-\mathrm{EF} / 2004 \text { of } 2 \text {. July } 2004 \text { laying down the terms } \\
\text { and conditions for converting agreements granting } \\
\text { timber supply guarantees and letters of intent into forest } \\
\text { concession contracts }\end{array}$ & Ministerial Order & $\begin{array}{l}\text { DRC-ministry of the environment, } \\
\text { conservation of nature and } \\
\text { sustainable development }\end{array}$ & 2004 \\
\hline $\begin{array}{l}\text { Ministerial Order } n^{\circ} 035 / \mathrm{CAB} / \mathrm{MIN} / \mathrm{ECN}-\mathrm{EF} / 2005 \text { of } \\
26 \text { May } 2005 \text { reporting Order } 071 \text { of } 22 \text { November } \\
2004 \text { and amending Order } 050 / \mathrm{CAB} / \mathrm{MIN} / \mathrm{ECN}- \\
\text { EF/2004 of } 2 \text { July } 2004 \text {. }\end{array}$ & Ministerial Order & $\begin{array}{l}\text { DRC- ministry of the environment, } \\
\text { conservation of nature and } \\
\text { sustainable development }\end{array}$ & 2005 \\
\hline $\begin{array}{l}\text { Decree } n^{\circ} 05 / 116 \text { of } 24 \text { October } 2005 \text { laying down the } \\
\text { terms and conditions for the conversion of forest titles } \\
\text { into forest concession contracts. }\end{array}$ & Presidential Decree & DRC Presidency & 2005 \\
\hline $\begin{array}{l}\text { DRC's parks and reserves Assessing the efficiency of } \\
\text { protected Areas' management }\end{array}$ & Report & IUCN & 2010 \\
\hline $\begin{array}{l}\text { Analysis of forest financing in the Democratic Republic } \\
\text { of Congo }\end{array}$ & Report & $\begin{array}{l}\text { Focal point (Malele Mbala), } \\
\text { United Nations Forum on Forest }\end{array}$ & 2010 \\
\hline $\begin{array}{l}\text { Analysis of the experience of forest reform in order to } \\
\text { draw the necessary lessons and contribute to the reform } \\
\text { of the mining sector in the DRC. }\end{array}$ & Report & WWF & 2012 \\
\hline $\begin{array}{l}\text { Fifth national report on the implementation of the } \\
\text { Convention on Biological Diversity }\end{array}$ & Report & $\begin{array}{l}\text { DRC- ministry of the environment, } \\
\text { conservation of nature and } \\
\text { sustainable development }\end{array}$ & 2014 \\
\hline
\end{tabular}

coalition for this purpose. In 1992-93 the coalition grew into a larger multi-stakeholder consultation known as the 'sovereign national conference' (Conférence nationale souveraine). A political transition was organised and substantially weakened the Mobutu's regime. This was the beginning of the end, and Mobutu's regime collapsed in 1997.

\section{Changing a political regime to establish 'good' governance}

The formulation and adoption of DRC's PAFT were concomitant with the formulation of a new forest law to replace the 1949 law. An expert who closely monitored this legal reform process reported that: "In April 1988, at an AGEF Board of 
TABLE 2 Summary and list of interviewees

\begin{tabular}{|c|c|c|c|c|}
\hline Qualification & Number & Affiliation institutions & Topic addressed & Attributed code \\
\hline \multirow{3}{*}{$\begin{array}{l}\text { University Professors and } \\
\text { Researchers in forest and } \\
\text { protected areas governance } \\
\text { in the DRC }\end{array}$} & \multirow[t]{3}{*}{7} & $\begin{array}{l}\text { University of Kinshasa and } \\
\text { ICREDES }\end{array}$ & \multirow{3}{*}{$\begin{array}{l}\text { Forest governance, the role of } \\
\text { international actors in forest } \\
\text { policy making and the } \\
\text { management of protected } \\
\text { areas in the DRC }\end{array}$} & \multirow{3}{*}{$\begin{array}{l}\text { Researcher (R) } \\
\text { R20200709; } \\
\text { R20200822; } \\
\text { R20200427; } \\
\text { R20200821; } \\
\text { R20200616; } \\
\text { R20200717 }\end{array}$} \\
\hline & & University of Kisangani & & \\
\hline & & Official University of Bukavu & & \\
\hline $\begin{array}{l}\text { Civil society national } \\
\text { organisation officials }\end{array}$ & 3 & $\begin{array}{l}\text { Council for the Defence of } \\
\text { the Environment through } \\
\text { Legality and Traceability } \\
\text { (CODELT) } \\
\text { Observatory of Forest } \\
\text { Governance (OGF) } \\
\text { National Coalition Against } \\
\text { Illegal Logging (CNCEIB) }\end{array}$ & $\begin{array}{l}\text { Forest governance } \\
\text { Forest concession, illegal } \\
\text { logging }\end{array}$ & $\begin{array}{l}\text { Congolese Civil } \\
\text { Society Organisation } \\
\text { (CCSO) } \\
\text { CCSO, 20201022; } \\
\text { CCSO, 20201023; } \\
\text { CCSO, 20200415 }\end{array}$ \\
\hline $\begin{array}{l}\text { Federation of Timber } \\
\text { Processing Companies } \\
\text { (FIB) }\end{array}$ & 1 & $\begin{array}{l}\text { Federation of Timber } \\
\text { Processing Companies (FIB) }\end{array}$ & $\begin{array}{l}\text { History of the moratorium and } \\
\text { the process of converting } \\
\text { assurance of supply(AoS) into } \\
\text { forest concession contracts } \\
\text { (FCC) in the DRC }\end{array}$ & $\begin{array}{l}\text { Private sector (PS) } \\
\text { PS-20201101 }\end{array}$ \\
\hline Congolese civil servants & 6 & $\begin{array}{l}\text { ministry of environment } \\
\text { (General Directorates of } \\
\text { Forests, Forest Management, } \\
\text { Inventory and Forest } \\
\text { Management and community } \\
\text { forestry) and the Directorate } \\
\text { of Geomatics }\end{array}$ & Forest governance & $\begin{array}{l}\text { Congolese Civil } \\
\text { Servants (CCS) } \\
\text { CCS20200624; } \\
\text { CCS20201015; } \\
\text { CCS20200929 }\end{array}$ \\
\hline World Bank & 1 & $\begin{array}{l}\text { World Bank Representative } \\
\text { to DRC }\end{array}$ & $\begin{array}{l}\text { The role of the World Bank in } \\
\text { the forest sector in the DRC }\end{array}$ & $\begin{array}{l}\text { World Bank (WB) } \\
20201028\end{array}$ \\
\hline Freelance consultants & 2 & $\begin{array}{l}\text { Retired senior civil servants } \\
\text { from the DRC ministry of } \\
\text { environment }\end{array}$ & $\begin{array}{l}\text { Conversion of forest titles, the } \\
\text { role of the World Bank in the } \\
\text { reform of the forest code }\end{array}$ & $\begin{array}{l}\text { Congolese consultant } \\
\text { (CC) } \\
\text { CC20201018 }\end{array}$ \\
\hline
\end{tabular}

Directors meeting the Canadian party decided to fund forest policy reform in the DRC. The initiative led to the drafting of a bill, which was tabled on several occasions e.g. during the symposium on tropical wood held in Kinshasa from 26 to 30 September 1989" (Sakata 2008:9) but it was never adopted because of the institutional and political unrest at the time.

Sustainable management of the industrial and artisanal logging sector was not a priority for the Mobutu regime. He seemed to focus more on nature conservation policies, because of the related international visibility e.g. he supported the 12th General Assembly on Nature Conservation in Kinshasa in September 1975 (IUCN 1976). The Mobutu government lacked interest in the logging sector which, - due to neo-patrimonial management, - had little to contribute to the national economy. Although at the time, deforestation reduction had little international visibility compared to the current growing global interest in tropical deforestation and the related climate change mitigation effect. This lack of interest was particularly obvious in the early 1970s when the University of Kinshasa closed its forestry department (Table 2, R20200709, CCS20200624, FAO 2003).

By the end of the cold war (1990), most of Mobutu's traditional allies no longer supported him and most of the technical cooperation with international institutions was suspended. This persuaded Mobutu to largely ignore sectors with weak international visibility such as the logging sector, since his priority was securing power and managing political crises.

Despite the political tension between international organisations and the Mobutu regime, the World Bank had not completely lost interest in changing the governance of the forestry sector: "In sparsely populated, forest-rich countries such as Zaire, there are still options to conserve natural forest and woodland [...] however, major investments should be preceded by policy reforms, and country capacity building, particularly in countries where the policy framework is poor and institutions weak." (World Bank 1994a:5) 
The promotion of this reform agenda would, however, be taking place in a deteriorating political situation. In 1996, the DRC fell into a severe political and security crisis, following the so-called 'liberation war' (guerre de libération) headed by one of Mobutu's main opponents, Laurent Désiré Kabila, who led a rebellion group named AFDL (Alliance des Forces Démocratiques pour la Libération).

The fall of the Mobutu regime in May 1997 restored hope that the new government under Désiré Kabila would pay more attention to the sustainability of the logging sector. However, the relative stability and peace in the country did not last as a few months later, in August 1998 (Pourtier 2002), two new rebel groups emerged. The MLC (Mouvement de libération $d u$ Congo) and the RCD (Rassemblement congolais pour la démocratie). The MLC and RCD uprisings added fuel to the local and neighbouring militia which operated the Kivu provinces of the DRC. Their violent looting of forest and mining resources had grown steadily worse since the Rwandan genocide of 1994 and the proliferation of rebel groups in eastern Congo.

Also in 1998, the UNDP, FAO and several Western development cooperation agencies (Canadian, Belgian, German, American, French and Swedish) wanted a series of meetings to be held in Kinshasa to draft a DRC Forest Code $^{7}$ that would establish 'good' governance in the forestry sector. The World Bank and the European Union agreed and felt that the adoption of a Forest Code would help set the stage for a reduction of inequalities through the introduction of a system for the fair redistribution of benefits in the forestry sector (Sakata 2008, Trefon 2008). The political aspect of the international initiative was expected to indirectly contribute to the restoration of social peace and economic development, particularly in the most forest-rich provinces (Ituri, Mongala, Tshuapa, Tshopo) especially since those provinces or regions had been plundered since the beginning of the political instability and the related uprisings of the 1990s. It took time for these reforms to bear fruit notably due to political tensions between some international organisations in the DRC and the Kabila regime. International organisations began to shy away from the increasing nationalism of Kabila's entourage and his increased advocating for the country's complete sovereignty in the governance of natural resources. This led to the reduction, suspension and in some cases the termination of funding programmes in many sectors including forestry (de Villers 2010, Table 2, R20200822, R20200427). In other words, tension between the international actors and the Kabila regime, a regime which was particularly reluctant to adopt the international agenda of 'good' governance and the related conditionality package, further exacerbated the forest governance crisis in the DRC.

Securing domestic interests by strategic good intentions The assassination of Laurent Désiré Kabila in January 2001 indirectly contributed to relaunching forest policy reforms in the DRC, whose conditional agenda was one of the points of contention between the Congolese government and the international organisations. Cooperation improved between international organisations involved in the forest policy reforms and the new regime of Joseph Kabila who succeeded his father as the head of Congo since the young Kabila seemed more accommodating and open to proposals from international actors (Table 2, R2020200821, R20200822). His attitude and first speeches convinced his partners who saw in him a young 'inexperienced' leader willing and 'ready to learn' (de Villers 2010). Joseph Kabila's attitude and posture yielded strong political support for his government from international actors during his first presidential term (Correia Amaral 2015, Table 2, R20200821). He was encouraged by a WB and IMF conditional debt cancellation programme as part of the HIPC (Heavily Indebted Poor Countries) initiative ${ }^{8}$. On the environmental front, the main condition of the HIPC initiative for the DRC was to undertake reforms in favour of sustainability in forest and mining governance.

With time, Joseph Kabila lost his apparent docility and eagerness for policy reforms promoted by international organisations. In the forestry sector in particular, disenchantment was reflected in the widespread use of opaque procedures and discretionary allocations of forest concessions to front companies, often Asian, created or informally supported by political and military elites (Table 2, CCSO-20201023). This duplicity and the strategic reversal of the Kabila regime's pledge to change the national natural resources governance system was characteristic of the use of extraversion (Bayart 2000) and 'cunning government' (Ongolo and Karsenty 2015) as a strategic behaviour to resist domination. In the DRC case, de Villers (2010) highlighted that at the beginning of his first presidential term Kabila's recurrent form of openness and a determined attitude were also often displayed by other Congolese leaders: 'It consists in taking advantage of dependency relationships in order to harness external resources mobilised for the quest and consolidation of domestic power.'

\section{Providing foreign expertise to influence domestic forest policy reforms}

The international agenda on 'good' governance and 'sustainable development' was a paradigm shift, with Congolese leaders more constrained to implement international decisions than to contribute to their formulation. Two examples clearly illustrate this situation.

- As of 1998, the international organisations (including the World Bank) became more anxious to change the mode of access to and management of forest concessions (Sakata 2008). They believed that the 11 April 1949 law on the Forest Code no longer corresponded to international environmental realities and the related

\footnotetext{
${ }^{7}$ In the same period, other countries in the region had or were also about to develop new forest codes including in Cameroon (1994), Republic of Congo (2000), and Gabon (2001).

8 https://www.imf.org/external/np/hipc/2002/cod/codpd.pdf
} 
global sustainability challenges. At the social level, Congolese forestry laws inherited from the colonial period no longer respected the principles of fair, participatory natural resources management globally adopted at the Rio Earth summit in 1992. In several cases, the vacuum in the existing legal framework led to conflict between the local communities that relied on forestlands for their livelihood and managers of forest concessions acquired without the participation of the former.

- Simplistic, obscure procedures based on informal negotiated principles were used in allocating forest titles and were considered to be one of the causes of 'bad'governance and endemic corruption in the forestry sector.

Due to the DRC's institutional weaknesses, international organisations felt their help was essential to guiding the Congolese government towards good forest governance practices. In April 2002, FAO experts drafted the first 155-sections of the new Forest Code, without much input from the Congolese side. After comments and recommendations from the World Bank, the draft code was extended to 161 sections in a version that was sent to the transitional Congolese parliament which immediately voted to adopt it with just a few minor amendments (Table 2, CCSO-20201023, R20200616). In fact, Sakata (2008) points out that the transitional parliament merely reduced the text from 161 to 156 sections by merging a few sections whose wording seemed similar.

Using cooperation as a soft coercion instrument for 'good' governance

In the early 2000s, the Kabila government revived the Forest Code reforms process and the DRC was subjected to the HIPC initiative. The Congolese leaders felt compelled to abide by the conditionalities for 'good' governance reforms imposed by the international financial organisations. The World Bank imposed four measures for 'better' governance of forest concessions (WWF 2012, Table 2, CCSO-20200415), namely the (i) implementation of the 2002 Forest Code with the upgrading of forest titles previously issued under discretionary and less than transparent conditions, (ii) the maintenance of a 'moratorium' on any new allocations of forestry concessions, (iii) the reform of the forest taxation regime, and (iv) the establishment of a real community forestry system. The objective of the last was to reduce the anthropogenic pressure exerted by local populations on primary forests (Table 2, CCSO 20200415, R20200717, CCSO 20201023).

The conversion of 'holders of assurance of supply' into holders of forest concessions (source of discord between international actors, the state and the private sector) was introduced in the 2002 Forest Code. Section 155 of this law reads: "Holders of assurance of supply or letter of intent shall, within one year following the entry into force of this law, convert them into forest concessions provided that they meet the exploitation requirements laid down in this law". The enforcement decision for this provision of the Forest Code was adopted in 2004 by the Ministry of Environment,
(MECNT) which is in charge of the forestry sector, through Order No.050/CAB/MIN/ECN-EF/ 2004. This order upset forest loggers who believed that Section 155 was clear enough and did not need additional provisions, but just the completion of some simple administrative procedures.

In order to reconcile the interests of the government and the logging companies, the ministry in charge of forestry (MECNT) published Order No.071/CAB/MIN/ECN-AE/ 2004 of 22 September 2004 amending the abovementioned Order No.050. This new decision allowed forest title holders who had equipment and a wood processing unit and were in good standing with the tax authorities to benefit from the automatic title conversion provision. Order No.071, drafted together with many key stakeholders, was not published in its original form. The Minister used his discretionary power to change the Order to satisfy the industrial logging operators (Table 2, CCSO-20201022). The ministerial order was well received by logging and processing companies, but angered the representatives of the World Bank and FAO representatives and the Congolese civil society, who demanded that the Order be amended or even annulled (WWF 2012, Correia Amaral 2015, Table 1, CCSO-20201023). The Minister of Environment opined that his decision was an act of national sovereignty, so no international organisation could call for its annulment. The World Bank, supported by FAO and the Congolese civil society won this 'boxing match' and Order No.071 was replaced on 22 November 2004 by Order No.035/CAB/ MIN/ECN-EF/2004 (WWF 2012, Table 2, CCSO-20201023).

Neither the Minister of Environment nor the ITF was satisfied with this decision, the product of political pressure exercised by the international organisations. To reach a consensus, the Minister summoned the stakeholders (World Bank, FAO, civil society, ITF, and government departments, notably the General Tax Directorate) for consultation meetings. After 5 days of heated debate, the meeting produced wording for a new ministerial order (No.067/CAB/MIN/ ECN-EF/2005 of 20 September 2005). But, before the Order was signed and published, the Minister amended it to cater to the timber processing companies. The World Bank and other organisations (FAO and Congolese civil society Organisations) were dissatisfied, again, and the publication was postponed (WWF 2012, Correia Amaral 2015, Table 2, R20200717, CCSO-20201023). For one of the ITF's members, who at that time was an ITF consultant, "The minister in office at the time was one of the best ministers the forest sector had ever had. He was a true diplomat. He knew how to reconcile national interests with those of donors. The objective was to save Congolese-owned companies" (Table 2, PS-20201101).

The World Bank representatives were disappointed and profoundly frustrated by the Minister's attitude. In a memorandum dated 7 October 2005, the World Bank required the Minister of Environment to "Halt all procedures for the processing of conversion files received after 3 March 2005, repeal Order 071 and restore Order 050, annul the letters of intent and the assurances of supply for farmers who were in arrears with the payment of the surface area tax in 2003 and 2004 [...]" The memorandum also urged President Joseph 
Kabila to "[...] maintain the 2002 moratorium by presidential decree until the implementation of new tendering methods provided for in the forest code and the completion of the conversion process under Order 050"9.

Following this memorandum, President Joseph Kabila signed Presidential Decree No.05/116 on 24 October 2005 laying down the terms and conditions for the conversion of old forest titles into forest concession contracts. The same decree also provided for the extension of the moratorium on the granting of logging permits.

The representative of the World Bank argued that: "The Bank's position during the period of conversion of forest titles was part of the 'country strategy', which is a document agreed between a host country and the World Bank, and which defines the country's priorities for a specific period. At the time, DRC's priority was to reorganise the forest sector, making the respect of rules critical" (Table 2, WB-20201028).

The decree displeased the industrial logging operators, but allowed the Congolese government to benefit from financial assistance from international organisations, including the World Bank, to ensure enforcement of the 2002 Forest Code.

\section{When formal interests meet a private agenda of informal} interests

The preamble to the 2002 DRC Forest Code highlights that this law "Complies with modern principles of forest resources management and international environmental conventions". (Code forestier 2002).

According to Sébastien Malele Mbala, National Focal Point of United Nations Forum on Forest, the DRC's commitment to sustainability in the 2002 Forest Code addresses five issues: i) cancelling logging contracts that were obtained or managed illegally as a result of the legacy of mismanagement, ii) using participatory forest zoning to apportion forests to conservation, sustainable production of forest-based goods and services, community management and other purposes, iii) expanding national parks and supplying forest-based environmental services to emerging global markets, iv) ensuring that timber production is organised around sound social and environmentally sustainable principles, v) introducing transparency and the participation of civil society organisations, rural people and indigenous communities in all aspects of forest management and biodiversity conservation (Malele Mblala 2010:4).

The implementation of this commitment became key to the priority agenda on forest policy reforms published in 2003 by the Ministry of Environment, Conservation of Nature and Tourism (RDC-MENCT 2003). The five-aforementioned issues summarize the formal interests of the State in changing forestry governance in the DRC. However, these formal interests contrast with the informal interests of the actors in power, e.g., the tendering system that was supposed to bring greater transparency to forest concession management was being hijacked by various instruments of fraud and corruption. The aim of these corrupt practices, which were particularly common during the political transition (2003-2006) and resurfaced in the last decade, was to reward certain political and military clients with the fraudulent and concealed allocation of low-cost logging concessions (Muzong Kodi 2008).

Interviews with officials from the Ministry of the Environment, Nature Conservation and Tourism, particularly from the Directorate of Inventories and Forest Management (DIAF), and the Directorate of Forest Management, confirm these practices: "One army general owns nearly 12 logging concessions registered under the name of a football team. These concessions have been identified, but nobody, not even the forest inspectors can go there. He acquires these concessions at a price I don't know and sells them to the Chinese. Following criticism from international NGOs, the Chinese changed the name of the company" (CCS 20201015).

According to observers of the DRC forest governance process (Table 2, PS-20201101, Correia Amaral 2015), the main purpose of Ministerial Order 049 of 11 September 2015 on timber exploitation was to preserve the informal interests of a handful of Congolese political decision-makers. This Order introduced a new component for small-scale operators, the so-called 'second category' operators who were given the right to own and operate small private forest concessions no bigger than 1000 ha per year without having to pay taxes such as the forest area fee. This Order also gave the second category small-scale operators the legal right to export their timber, a privilege that had been granted only to industrial operators who had their own wood processing factories (Correia Amaral 2015). This Order angered the private industrial sector and the local communities whose positions had been passed on by national and international conservation NGOs.

The private sector felt that Order 049 introduced unfair competition and favoured the small-scale operators whose annual production already accounted for more than $75 \%$ of the DRC national timber production (Stephens 2015, Correia Amaral 2015). One of the members of industrial timber federation (ITF) said: "The only purpose of this Order is to clearly show the determination of the Congolese government and the Minister who signed this order to get rid of the industrial producers. And yet, the number of these producers is constantly going down because of the many taxes, most of which are contradictory" (Table 2, PS-20201101).

On the other hand, for the forest conservation NGOs, the objective of this Order was to circumvent the moratorium that suspends the attributions of the new forest concessions established in 2002 under pressure from international organisations. This includes the World Bank whose aim, inter alia, was to limit the pillage of the Congolese forests, which had increased during the 2003-2006 political transition period. Furthermore, this Order created a loophole for the formalisation and the proliferation of various transactions and deals

\footnotetext{
9 https://fr.allafrica.com/stories/200510250732.html
} 
allowing quick exploitation of the Congolese forests by subcontracting with Asian and Chinese operators in particular (Table 2, CC20201018, Correia Amaral 2015).

Responding to the sharp reactions to the preceding Order, the Minister of the Environment signed another Order (050) on forest timber operations. The second one was signed on 25 September 2015 after protests over and rejection of the first one. The main objective of the second order was to try to reduce the tension by explaining (Article 5, Para 2) that a 500 hectares' piece of land could be allocated to a second category small-scale operator, which was half the initial figure. The order also specified that this type of secondgeneration artisanal logging would only be authorized for individual people or entities of Congolese nationality or ruled by Congolese law, that come from the communities bordering the forests concerned and that their activities would henceforth by subjected to the provisions of an annual operating plan. Order 049 was cancelled but the new Order (050) did not solve all the issues brought up by the parties. There were some major claims that remained outstanding, namely, (1) the absence of any legal basis for the articles that created the Artisanal Forest Units (UFA), (2) the reduction in the rights of the local communities and the indigenous people as a result of the substantial reduction in the surface area of the forest concessions allocated to the local communities, and (3) the risk connected to the legalisation of the semi-industrial timber exploitation that included a considerable risk of abusively using the so-called second generation timber exploitation permits (Buttoud and Nguinguiri 2016). Despite this opposition, the second order (050) was applied for 11 months. A member of one of the organisations that protested about the publication of the two orders (049 and 050) said that: "By signing these orders, the Minister was prioritising his personal interests since he himself was a large artisanal operator." (Table 2, PS-20201101).

After the ministerial reshuffling of 26 September 2015, the fact that the Minister of the Environment was replaced gave the protesters new hope and encouraged them to take a harder position and demand for the cancellation of Order No. 050 whose content, they felt was not in line with efforts to introduce 'good' governance in the forest sector. The protesters coalition held several sessions to coordinate their position. Some of the sessions were held in the Nganda centre and at the head office of CODELT, an environmental defence NGO. Following these sessions and continued pressure and demands from civil society coalitions, two new ministerial orders (084 and 085) were signed on October 29 2016. The protesters participated considerably in drafting the two new orders, which were supported by all parties. Order No. 084 revoked the disputed Order No. 050 and set the limit to the size of the land that could be allotted to a second category artisanal exploitation at 50 hectares, rather than the previous 500 hectares. The second order, no. 085, signed by the new minister spelt out the procedure for creating a new forest management unit (UFA), management conditions, and the conditions for covering the socio-economic needs of the communities around the UFA.
Apart from these specific examples of conflict of interests in the forest administration, Table 3 summarizes the formal and informal interests of key actors of the forest policy reform.

$R E D D+$ as a new way to promote 'good' governance

The World Bank's early ambition for a forest policy reform agenda for the DRC waned since the inspection panel (Forget 1996) took a stand in favour of indigenous people in its report in August 2007. It all started with a letter sent on 19 November 2005 by organisations of the indigenous Pygmy people and their supporters to the World Bank. In this letter, petitioners blamed the World Bank for encouraging the Congolese government to prioritise and promote industrial logging exploitations and revise the forest taxation scheme without appropriate forest zoning to guarantee the rights of indigenous peoples. Furthermore, the intervention of the World Bank did not reckon with the post-conflict context (World Bank 2007, Debroux et al. 2007, Trefon 2008,). After investigating the Equateur and Orientale provinces, the WB Inspection Panel had, in a report submitted to the Bank on 31 August 2007, ruled in favour of the indigenous Pygmy people and their supporters, while acknowledging that the WB Board of Directors had been misled (World Bank 2007). The inspection experts estimated that 'the future of tropical forests depends on community forests and remuneration for stored carbon. The World Bank has since cautiously retreated into a the role of an economic analyst to the governments, while investing in the REDD+' (Karsenty 2020: 13), process in which the DRC has been engaged since 2009.

One of DRC's main strategies for acquiring international funding has been to adopt the discourse of international organisations (donors) in favour of 'good' governance in the forestry sector, including for REDD+ of course and at the same time sabotaging its implementation. Regarding climate change policies, the World Bank has for example included combating climate change in its Poverty Reduction Strategy Paper (PRSP-2 2011-2015) which has been included in the investment phase of its REDD+ process. Thanks to its position in support of climate change control, the Congolese government has already benefited from the multi-donor Central African Forest Initiative (CAFI) since 22 April 2016 when the letter of intent was signed. The caveat was that these funds would be used to fight deforestation by implementing policy reforms that would bring about 'good' governance in forest-related sectors that constitute the seven pillars of the national REDD+ strategy, namely forestry, agriculture, energy, land use planning, land use, demography, and governance.

Although the Congolese government agreed in principle to the CAFI initiative by signing the letter of intent, the forest administration's second thoughts about the status of logging concessions granted during the political instability period (période de transition) have often impeded the efficient roll out of the initiative. The CAFI Board of Directors has often considered the moratorium as a 'major prerequisite' to its support for the Congolese forest sector and the implementation 
TABLE 3 Overview of the formal and informal interests of the key actors of forest governance reforms in DRC

\begin{tabular}{|c|c|c|c|}
\hline Actors & Major formal interest & Major informal interest & Power element used \\
\hline $\begin{array}{l}\text { Congolese Government } \\
\text { and Presidency }\end{array}$ & Improve forest governance & $\begin{array}{l}\text { Capture external funding } \\
\text { Receive support from } \\
\text { international organisations }\end{array}$ & $\begin{array}{l}\text { Discourse, discretionary power, } \\
\text { promises and asymmetric } \\
\text { information to resist domination }\end{array}$ \\
\hline $\begin{array}{l}\text { International financial } \\
\text { organisations (IFM, WB) }\end{array}$ & $\begin{array}{l}\text { Aligning forestry sector with } \\
\text { governance principles; } \\
\text { Internalising conventions that } \\
\text { promote sustainable forest } \\
\text { management } \\
\text { Formalise the timber processing } \\
\text { sector identified as a high } \\
\text { economic potential sector to } \\
\text { enable the country pay its debts }\end{array}$ & $\begin{array}{l}\text { Imposing an international agenda } \\
\text { on the 'globalisation' of forest } \\
\text { governance in DRC } \\
\text { Maintaining a strong dependency } \\
\text { of the DRC vis-à-vis international } \\
\text { actors }\end{array}$ & $\begin{array}{l}\text { Financial incentive (loan); } \\
\text { conditionality }\end{array}$ \\
\hline $\begin{array}{l}\text { Bilateral cooperation } \\
\text { agencies (Norad, GIZ, } \\
\text { AFD, Belgian, Canadian, } \\
\text { USAID) }\end{array}$ & $\begin{array}{l}\text { Help the DRC to manage its } \\
\text { forest sustainably; } \\
\text { Promoting 'good governance' in } \\
\text { the forest sector. }\end{array}$ & $\begin{array}{l}\text { Maintaining geopolitical } \\
\text { influence; influencing domestic } \\
\text { policies }\end{array}$ & $\begin{array}{l}\text { Financial incentives; Dominant } \\
\text { information through foreign } \\
\text { expertise and capacity building }\end{array}$ \\
\hline $\begin{array}{l}\text { Multilateral United } \\
\text { Nations Agencies (FAO, } \\
\text { UNDP, UNEP) }\end{array}$ & $\begin{array}{l}\text { Supporting state bureaucracies } \\
\text { in fighting against deforestation; } \\
\text { Promoting sustainable forest } \\
\text { management practices }\end{array}$ & $\begin{array}{l}\text { Influencing law formulation; } \\
\text { influencing policy reform }\end{array}$ & Expertise \\
\hline $\begin{array}{l}\text { International non- } \\
\text { governmental } \\
\text { organisations of } \\
\text { conservation (UICN, } \\
\text { WWF, WCS, Rainforest, } \\
\text { Greenpeace) }\end{array}$ & $\begin{array}{l}\text { Promoting biodiversity } \\
\text { conservation }\end{array}$ & $\begin{array}{l}\text { Altering the hegemony of state } \\
\text { bureaucracies; Expanding and } \\
\text { reinforcing local civil society } \\
\text { organisations }\end{array}$ & $\begin{array}{l}\text { Dominant information through } \\
\text { counter-expertise on } \\
\text { environmental issues and } \\
\text { 'blame and shame' campaign }\end{array}$ \\
\hline $\begin{array}{l}\text { National state } \\
\text { bureaucracies (Ministry } \\
\text { in charge of forestry } \\
\text { sector) }\end{array}$ & $\begin{array}{l}\text { Internalising global } \\
\text { environmental and sustainability } \\
\text { regimes and related norms }\end{array}$ & $\begin{array}{l}\text { Fostering a sovereign use of forest } \\
\text { resources; encouraging forest } \\
\text { exploitation for economic } \\
\text { purposes; preserving rent seeking } \\
\text { for political and military elites } \\
\text { Challenging state authority; } \\
\text { Gaining international support }\end{array}$ & $\begin{array}{l}\text { Coercion; discretionary power; } \\
\text { erratic law implementation }\end{array}$ \\
\hline $\begin{array}{l}\text { Congolese Civil Society } \\
\text { Organisation }\end{array}$ & $\begin{array}{l}\text { Defending local communities' } \\
\text { rights; Avoiding inequality to } \\
\text { the access and use of forest } \\
\text { resources }\end{array}$ & $\begin{array}{l}\text { Attracting funding from } \\
\text { transnational conservation NGOs; } \\
\text { gaining an international } \\
\text { recognition; increasing their } \\
\text { external legitimacy }\end{array}$ & $\begin{array}{l}\text { Advocacy coalition with } \\
\text { international NGOs; blame and } \\
\text { shame' campaign }\end{array}$ \\
\hline $\begin{array}{l}\text { Private sector (federation } \\
\text { of industrial Logging } \\
\text { companies) }\end{array}$ & $\begin{array}{l}\text { Sustainable forest management; } \\
\text { low impact exploitation }\end{array}$ & $\begin{array}{l}\text { Exploiting Forests Without } \\
\text { Sustainability Constraints }\end{array}$ & $\begin{array}{l}\text { Providing formal and informal } \\
\text { incentives to get forest } \\
\text { concessions or avoiding } \\
\text { penalties for illegal logging, } \\
\text { etc.; using financial incentives } \\
\text { to get support from politicians } \\
\text { and other allies. }\end{array}$ \\
\hline
\end{tabular}

of the REDD+ mechanism. According to them, this moratorium aimed at improving the governance would contribute to the achievement of conditions needed to lift the moratorium, all the while making it possible to fight illegal operations and address some of the causes of deforestation ${ }^{10}$.

\section{On the involvement of local population and pygmies in 'good' forest good governance}

Community forestry for instance was considered as a new approach wherein management contracts between the

10 https://www.cafi.org/content/cafi/fr/home/all-news/CAFI-Statement-illegal-logging-concessions-DRC-Feb-2018.html consulted on April 8, 2021. 
government and local communities held the latter responsible for managing their own forestlands, which would contribute to good forest governance and local development in DRC (Debroux et al. 2007, Buttoud and Nguinguiri 2016).

Community forest development started in DRC in 2005 prompted by the FAO's recommendations on forest management. The Congolese government, through its forestry administration, had requested FAO assistance in developing community forestry (Maindo and Kapa 2014). This led to the 2007-2012 FORCOM (community forestry) project developed and funded by Belgian Technical Assistance (CTB). Alongside FORCOM, an NGO called Forests Monitor developed a project named FORCOL (local community forests) that was funded in 2009 by the British government through its Department for International Development (DFID) for an 18-month period (Samyn et al. 2010). The decree defining the terms and conditions for allocating community forests was published in 2014. The Ministerial order on the management and exploitation of local community forest concessions was published two years later, in 2016. In other countries in the Congo Basin, such as Cameroon, the community forestry system is usually organised around one component, while in DRC the system is structured around two: the local communities' forest concessions and the local communities' forests. The purpose of the two components is to increase the local communities' participation and responsibility in forest management and operations and thereby enable the forest sector to contribute more to local development. But some evaluations of the community forestry in DRC emphasize that there are many obstacles to the implementation of the process, which make it difficult to reach the goals, especially to improve the participation and the local development of the riparian populations (Buttoud and Nguinguiri 2016, Lescuyer et al. 2019). In addition, some members of the Barumbi Tshopo community forest in the Bafwasende Territory, Tshopo Province, felt the goals were unrealistic and that the advantages of community forestry that were presented were pies in the sky.

\section{DISCUSSION}

In this paper, we analysed the various attempts made by international organisations to establish 'good' governance in the forestry sector, either through unilateral efforts or through coalitions with other non-State actors involved in the DRC forest governance. The following results partly confirm our hypothesis that international organisations such as the World Bank have a strong impact on the DRC through various tools of pressure and power designed to impose 'good' governance in the DRC forests.

We have wondered if the DRC political decision-makers and elites use socio-political chaos and crises to parry the domination of international organisations and sometimes impose their own private agendas on the forest sector. In most cases, this resistance to international demands for 'good' governance is often disguised in more, or less, sincere rhetoric to defend national sovereignty, when confronted with proponents of reform policies that camouflage intervention strategies in the governance of the natural resources in DRC. This tendency is not unique to DRC. Bayart (2000) stressed the extraversion capacity of developing countries to resist international demands even during the structural adjustment programs imposed by the international financial institutions. In the Central African forest governance sector, decision makers often resist attempts at external domination by using institutional and structural weak points of countries under pressure. In Cameroon, for instance, the resulting more or less subtle tensions often turn into a cunning government (Ongolo and Karsenty 2015) where the formerly dominated actors use cunning to oppose their dominating counterparts. Taking the example of environmental cooperation between countries in the Congo Basin and certain partners in the West, Nago and Krott, (2020) document similar situations in north-south relations in the fight to control climate change.

Studies conducted in Central Africa, e.g. Cameroon, indicate that the reform measures supported by the World Bank, as of the early 1990s, were not able to bring about in-depth changes to the forest sector governance system (Fournier and Karsenty 2008, Karsenty 2017). In the DRC, frequent violations of the moratorium, and disputes concerning the Ministerial orders on small-scale timber operations are telling examples of the quasi-legal strategies that the government and their political allies, or the economic sectors can use to avoid external requirements that might compromise their interests. Denunciation by civil society organisations that benefit from media coverage of their 'blame and shame' campaigns sometimes manage to expose murky natural resources practices very commonly found in Central Africa, especially in DRC. But in most cases, the other better structured counter-forces, whose main role should be to control government actions (parliaments) and/or ensure strict application of the law (judiciary) very rarely try to improve the governance methods and practices applied to natural resources. Trying to reverse this withdrawal, together with a substantial improvement of the education system related to forestry and natural resources governance, are two of the biggest challenges to meet global sustainability, if the rule of law is to be adopted in countries such as the DRC. Such a change in the governance of forestlands is particularly needed in this country since private interests and informality are the overriding factors in the forest-related governance processes.

\section{CONCLUSION}

This paper examines the reasons for the failure of forest governance in the Democratic Republic of Congo (DRC) and the politics involved. It hypothesises that international organisations and transnational conservation NGOs tried to employ power strategies including financial incentives, dominant information and forest policy expertise, to impose 'good' governance in the Congolese forestry sectors. However, the attempts of international organisations to dominate have 
been countered by the skilful strategies of domestic decisionmakers and political elites who want the 'undesired' forest policy reforms to lose so that their private interests and their 'quest for sovereignty' can win.

Our research used theoretical and empirical approaches to show that the influence of international actors in DRC forestland governance is made either autonomously or through the formation of sporadic coalitions with inter alia logging companies and local NGOs. More specifically, the domination power strategies of international actors in DRC include: i) incentive-based strategies (conditionality of international aid, intermittent and targeted allocations of international funding through projects, promises of support, etc.) and ii) domination by information (policy reforms based on external expertise, 'blame and shame' campaigns in coalitions with conservationist NGOS and media), etc.

In the DRC forest policy processes, each category of actors sought to make its interests prevail (formal/informal). The resulting political rivalries worsened the governance crisis and the related policy failures. Admittedly however, the intervention of international organisations, especially the World Bank, sometimes led to symbolic policy changes, although often reversible, in the forestry sector.

In this paper, we have shown that the governance crisis that has plagued the DRC forest sector since the 1980s, has not been overcome by the intrusive 'good' governance interventions mobilized by international organisations. The lingering ongoing crisis in the forestry sector is the result of several forms of opposition by State bureaucracies and political elites to the injunctions of 'good' governance promoted by international actors and their allies.

To reverse this trend will require the revision of the forest law and implementation measures to acquiesce to the new demands for the preservation of biodiversity, compliance with the law on the allocation of forest concessions, stronger forest controls, consideration of the needs of local populations and indigenous people, etc. In short, the major challenge facing the Congolese State is to meet global sustainability goals at the national level. This goal is inextricably linked to the State's capacity and the political interest of its policy-makers and ruling elite to implement the rule of law as stated by national legislation in the forest sector. It is essential to enhance governance processes and forestland sustainability through greater institutional capacity building combined with substantial improvements in the DRC education system.

\section{ACKNOWLEDGMENTS}

The authors acknowledge Le Mans University and Pays de Loire region in France for financing the $\mathrm{PhD}$ research of the first author of this paper. The authors are also grateful to the Volkswagen Foundation, which supported this research through the project "The forestry sector as an inequality machine? Agent, agreements and global politics of trade and investment in the Congo basin" - A.Z. 96964 (FOREQUAL). We are very thankful to Tilly Gaillard for thoroughly editing this paper. We warmly thank the anonymous reviewers of this paper for their valuable comments and suggestions.

\section{REFERENCES}

ALI, M. 2019. Governance and good governance: A conceptual perspective. Journal Of Public Administration And Governance 10(1): 65-77.

AQUINO, A., and GUAY, B. 2013. Implementing Redd+ in the democratic republic of congo: An analysisi of the emerging national Redd+ governance strucutre. Forest Policy And Economics 36: 71-79. Https://Doi.Org/ 10.1016/J.Forpol.2013.04.003

BAYART, J.F. 2000. Africa in the world: A history of extraversion. African Affairs 99(395): 217-267. Https://Doi. Org/10.1093/Afraf/99.395.217

BERNSTEIN, S., and CASHORE, B. 2012. Complex global governance and domestic policies: Four pathways of influence. International Affairs 88(3), 585-604. Https:// Doi.Org/10.1111/J.1468-2346.2012.01090.X

BETSILL, M., and CORELLE, E. 2001. Ngo influence in international environmental negotiations: A Framework For Analysis. Global Environemental Politics 1(4): 65-85. Https://Doi.Org/10.1162/152638001317146372

BURNLEY, C. 2011. Policy natural resources conflict in the Democratic Republic of the Congo: A question of governance? Sustainable Development Law And Policy 12(1): 7-11. Http://Digitalcommons.Wcl.American.Edu/Sdlp

BURNS, S.L., KROTT, M., SAYADYAN, H.Y, and GIESSEN, L. 2017. The world bank improving environmental and natural resource policies: Power, deregulation, and privatization in (post-Soviet) Armenia. World Development 92: 215-224. Https://Doi.Org/10.1016/J.Worlddev.2016. 12.030

BUTTOUD, G., and NGUINGUIRI, J.-C. 2016. L'avenir des Modes de Gestion inclusive des forêts d'Afrique centrale. In. Buttoud, G., and Nguinguiri, J.C. (Eds.), La gestion Inclusive des forêts d'Afrique centrale: Passer de la participation au partage des pouvoirs (Pp. 225-235). Fao-Cifor. Http://Agritrop.Cirad.Fr/580835/1/Id580835.Pdf

CLÉMENT, J. 1994. Les programmes d'action forestiers nationaux. Aménagement et Nature 115: 81-86.

CODE FORESTIER. 2002. Loi N ${ }^{\circ} 011 / 2002$ Du 29 Aout 2002 Portant Code Forestier.

CORREIA AMARAL, F.C. 2015. Des relations impossibles: Conflits associés à la mise en ouvre d' une gestion durable des forêts en Rdc.

CROZIER, M., and FRIEDBERG, E. 1977. L'acteur et le Système, (Editions D).

DE LA HARPE, S., RIJKEN, C., and ROOS, R. 2008. Good governance. Potchefstroom Electronic Law Journal (Pelj) 11(2). Https://Doi.Org/10.1093/Oxfordhb/9780199560530. 013.0010

DE VILLERS, G. 2010. Le Congo/Zaïre Indépendant: Permanences Et Changements. Outre-Mers 97(368): 177-193. Https://Doi.Org/10.3406/Outre.2010.4497

DEBROUX, L., TOPA, G., HART, T., KAIMOWITZ, D., KARSENTY, A., ABDON, A., and BRAVI, C. 2007. Forests in post-conflict democratic republic of congo: Analysis of a priority agenda, 107pp.

DKAMELA, G.P., BROCKHAUS, M., DJIEGNI, F.K., SCHURE, J., and MVONDO, S.A. 2014. Lessons For 
Redd+ from Cameroon's past forestry law reform: A political economy analysis. Ecology And Society 19(3): 30. Https://Doi.Org/10.5751/Es-06839-190330

DOHERTY, E., and SCHROEDER, H. 2011. Forest tenure and multi-level governance in avoiding deforestation under Redd. Global Environmental Politics 11(4): 66-88. Https://Doi.Org/10.1162/Glep_A_00084

DOORNBOS, M. 2006. 'Good governance': The metamorphoses of a policy metaphor. Global Forces And State Restructuring 57(6): 73-92. Https://Doi.Org/10.1057/978 0230502154_4

DOUMENGE, C. 1990. Conservation des ecosystemes du zaire, UICN (Ed.), 261pp.

EHRENSTEIN, V. 2013. Les professionnels de la préparation. aider la République Démocratique du Congo à réduire sa déforestation: Programme Redd+. Sociologies Pratiques 27(2): 91-104. Https://Doi.Org/10.3917/Sopr. 027.0091

EKOKO, F. 2000. Balancing politics, Economics and Conservation: The Case of the Cameroon forestry law reform. Development And Change 31(1): 131-154. Https://Doi. Org/10.1111/1467-7660.00149

ELAHI, K.Q.I. 2009. UNDP on good governance. International Journal Of Social Economics 36(12): 1167-1180. Https://Doi.Org/10.1108/03068290910996981

ETZIONI, A.1975. A Comparative Analysis Of Complex Organizations: On Power, Involvement, And Their Correlates (F. Press (Ed.); 2nd, Illustr Ed.).

FAO. 2003. Situation des ressources génétiques forestières de la République Démocratique Du Congo, 44pp.

FOUCAULT, M. 1978. On governmentality, Lecture at the College de France. In The Foucault Effect: Studies In Governmentality (G. Burchell, C. Gordon, And P. Miller (Eds.)). Hemel Hemp-Stead: Harvester Wheatsheaf.

FOURNIER, P., and KARSENTY, A. 2008. Etats "défaillants": le secteur forestier en Afrique. Cairn.Info 36(143): 43-57.

GISSELQUIST, R. 2012. Good governance as a Concept, and why this matters for development policy, UNU-WIDER Working Paper, 30pp.

GORDON, C. 1980. Power-knowledge: Selected Interviews and other writings (1972-1977) by Michel FOUCAULT. In C. Gordon (Ed.), Pantheon Books. The harverster press, Press. Https://Doi.Org/10.1007/978-1-4614-5583-7_438

GRINDLE, M.S. 2010. "Good governance: The inflation of an idea". In Harvard University, Cambridge (Vol. 19, Issue 3). Https://Doi.Org/10.5874/Jfsr.19.225

HANSEN, C.P., LUND, J.F., and TREUE, T. 2009. Neither fast, nor easy: The prospect of reduced emissions from deforestation and degradation (Redd) in Ghana. International Forestry Review 11(4): 439-455. Https://Doi.Org/ 10.1505/Ifor.11.4.439

Hoogeveen, H., and Verkooijen, P. 2010. Transforming Sustainable Development Diplomacy: Lessons Learned From Global Forest Governance. Https://Books.Google.Com/ Books/About/Transforming_Sustainable_Development_ Dip.Html?Id=Hz3dsaaacaajandpgis $=1$

IUCN. 1976. Report of the 12th general assembly, 293pp.
IUCN. 2010. Parcs et réserves de la République Démocratique du Congo: Evaluation de l'efficacité de la gestion des aires protégées, 140pp.

KABAMBA, P. 2010. 'Heart of darkness': Current images of the Democratic Republic of the Congo and their theoretical underpinning. Sage Publications 10(3): 265301. Http://Ant.Sagepub.Com

KARSENTY, A. 2017. The world bank's endeavours to reform the forest concessions' regime in central Africa: Lessons from 25 years of efforts. International Forestry Review 19: 64-79. Https://Doi.Org/10.1505/1465548178 22295948

KARSENTY, A. 2020. Géopolitique des forêts d' Afrique centrale. Hérodote, Révue De Géographie Et De Géopolitique 179: 108-129.

KATSAMUNSKA, P. 2016. The concept of governance and public governance theories. Economic Alternatives 2: 133-141.

KEPING, Y. 2018. Governance and good governance: A new framework for political analysis. Fudan Journal of The Humanities And Social Sciences 11(1): 1-8. Https://Doi. Org/10.1007/S40647-017-0197-4

KROTT, M. 2005. Forest policy analysis. In European Forest Institute. Https://Doi.Org/10.1007/1-4020-3485-7

KROTT, M., BADER, A., SCHUSSER, C., DEVKOTA, R., MARYUDI, A., GIESSEN, L., and AURENHAMMER, H. 2014. Actor-Centred Power: The Driving Force In Decentralised Community Based Forest Governance. Forest Policy And Economics 9. Https://Doi.Org/10.1016/ J.Forpol.2013.04.012

LATEEF, K.S. 2016. Evolution of the World Bank's thinking on governance. January 44.

LAWSON, S. 2014. Illegal logging in the Democratic Republic of the Congo. Chatham House 29.

LESCUYER, G., KAKUNDIKA, T.M., LUBALA, I.M., EKYAMBA, I.S., and TSANGA, R. 2019. Are community forests a viable model for the Democratic Republic Of Congo? Ecology And Society 24(1): 15.

LOUIS FORGET, M. 1996. Le «panel d'inspection» de la Banque Mondiale. Annuaire Français de Droit International 42: 645-661. Https://Doi.Org/Https://Doi.Org/ 10.3406/Afdi.1996.3406

MAINDO, A., and KAPA, F. 2014. La foresterie communautaire En Rdc: Premières expériences, défis et opportunités. Tropenbos International Rd Congo, 159pp.

MAJAMBU, E., NZIAVAKE, S., HANGI, R., MAMPETA, S., KIPUTE, D.D., and SONWA, D.J. 2020. Governing wildlife resource in Drc: Challenges of local actors in Rubi-Tele hunting domain, Tufs.Ac.Jp Working Paper, $11 p p$.

MALELE MBALA, S. 2010. Analysis of forest financing in the Democratic Republic Of Congo, UNFF national focal point report, 22pp.

MAMPETA WABASA, S. 2017. Repenser le rôle des institutions de conservation de la nature à l'ère de la globalisation en Afrique: À propos du parc national de la Salonga (Rdc). European Scientific Journal, Esj 13(11): 92. Https://Doi.Org/10.19044/Esj.2017.V13n11p92 
MARQUANT, B., MOSNIER, A., BODIN, B., DESSARD, H., FEINTRENIE, L., MOLTO, Q., GOND, V., and BAYOL, N. 2015. Importance des forêts d'Afrique centrale. In. De Wasseige, C., Tadoum, M. Eba'a Atyi R., and Doumenge, C. (Eds.), Les forêts du Bassin du Congo (P. 128).

MAYAUX, P., PEKEL, J.F., DESCLÉE, B., DONNAY, F., LUPI, A., ACHARD, F., CLERICI, M., BODART, C., BRINK, A., NASI, R., and BELWARD, A. 2013. State and evolution of the African rainforests between 1990 and 2010. Philosophical Transactions of the Royal Society B: Biological Sciences 368(1625). Https://Doi.Org/10.1098/ Rstb.2012.0300

MINTROM, M., and VERGARI, S. 1996. Advocacy coalitions, policy entrepreneurs, and policy change. Policy Studies Journal 24(3): 420-434. Https://Doi.Org/10.1111/J.15410072.1996.Tb01638.X

MUZONG KODI. 2008. Corruption and governance in the DRC during the transition period (200-2006). In Institute For Security Studies (Issue 148). Https://Doi.Org/ 10.1007/978-3-662-61285-9_8

NAGO, M., and KROTT, M. 2020. Systemic failures in north - south climate change knowledge transfer: A case study of the Congo Basin. Climate Policy 0(0): 1-14. Https:// Doi.Org/10.1080/14693062.2020.1820850

NANDA, V.P. 2006. The "good governance" concept revisited. Annals of the American Academy of Political and Social Science 603: 269-283. Https://Doi.Org/10.1177/ 0002716205282847

OCHIENG, R.M., VISSEREN-HAMAKERS, I.J., ARTS, B., BROCKHAUS, M., and HEROLD, M. 2016. Institutional effectiveness of Redd+ MRV: Countries progress in implementing technical guidelines and good governance requirements. Environmental Science and Policy 61: 4252. Https://Doi.Org/10.1016/J.Envsci.2016.03.018

ONGOLO, S., and KARSENTY, A. 2015. The politics of forestland use in a cunning government: Lessons for contemporary forest governance reforms. International Forestry Review 17(2): 195-209. Https://Doi.Org/10.1505/ 146554815815500561

OSMONT, A. 1998. La «governance»: Concept mou, politique ferme. Les Annales de la Recherche Urbaine 80(1): 19-26. Https://Doi.Org/10.3406/Aru.1998.2193

OYONO, P.R. 2004. One step forward, two steps back? Paradoxes of natural resources management decentralisation in cameroon. Journal Of Modern African Studies 42(1): 91-111. Https://Doi.Org/10.1017/S0022278x03004488

PAFT_RDC. 1989. Plan d'action forestier tropical du Zaire. foresterie et utilisation des Terres: Reboisement et foresterie rurale (1ère Partie: Reboisements), 76pp.

PLUMPTRE, T., and GRAHAM, J. 1999. Governance and good governance: International and aboriginal perspectives. Journal of Policy and Administration, 1-27.

POURTIER, R. 2002. The Congo (DRC) amid war and plunder. Bulletin de l'association de Géographes Français, 79(2): 251-263.Https://Doi.Org/10.3406/Bagf.2002.2274
RAHMAN, M.S., and GIESSEN, L. 2017. Formal and informal interests of donors to allocate Aid: Spending patterns of USAID, GIZ, and EU forest development policy in Bangladesh. World Development 94: 250-267. Https:// Doi.Org/10.1016/J.Worlddev.2017.01.012

RDC-MENCT. 2003. Agenda prioritaire pour la relance du secteur forestier, Ministère de l'environnement, Conservation de la Nature et Tourisme, 6pp.

RDC-PNFOCO. 2003. Rd Congo plan national forêts et conservation, $42 p p$.

RENAUD, G. 1995. Le formel et l'informel: Une tension créatrice continuelle. Théologiques 3(1): 129-152. Https://Doi.Org/10.7202/602419ar

SABATIER, P.A. 1987. Knowledge, policy-oriented learning, and policy change. In Knowledge (Vol. 8, Issue 4). Https:// Doi.Org/10.1177/0164025987008004005

SABATIER, P.A. 1999. A comparison of frameworks, theories, and models of policy processes. In Theories of the policy process. Https://Doi.Org/10.1081/E-Epap2120041405

SAKATA, G. 2008. Le droitforestier en République Démocratique du Congo, études juridiques de la FAO en ligne, 19pp. (www.Fao.Org/Legal/Prs-Ol/Paper-E.Htm).

SAMYN, M.J., KARPE, P., and MAMPETA, S. (2010). Projet de développement et de la mise en auvre de la foresterie communautaire en République Démocratique du Congo, 117pp.

SANTISO, C. 2014. Good governance and aid effectiveness: The world bank and conditionality. The Georgetown Public Policy Review 7(1): 22.

SCHOENER, W. 1997. Non-governmental organizations and global activism: Legal and informal approaches. Indiana Journal Of Global Legal Studies 4(2): 10.

SCHUSSER, C., KROTT, M., MOVUH, M.C.Y., LOGMANI, J., DEVKOTA, R.R., MARYUDI, A., and SALLA, M. 2016. Comparing community forestry actors in cameroon, indonesia, namibia, nepal and germany. Forest Policy and Economics 68: 81-87. Https://Doi. Org/10.1016/J.Forpol.2016.03.001

SEYMOUR, F.J., DUBASH, N.K., BRUNNER, J., EKOKO, F., FILER, C., KARTODIHARDJO, H., and MUGABE, J. 2000. The Right Conditions: The World Bank, Structural Adjustment, and forest policy reform. World Resources Institute, 166pp.

SHARPE, B. 1998. 'First the forest': Conservation, 'community' and 'participation' in South-West Cameroon. Journal Of The International African Institute 68(1): 25-45.

STEPHENS, M. 2015. Rapport sur l'étude de cadrage du secteur forestier en RDC, 76pp.

TREFON, T. 2008. La réforme du secteur forestier en république démocratique du congo: Défis sociaux et faiblesses institutionnelles. Afrique Contemporaine 3(227): 81-93. Https://Doi.Org/10.3917/Afco.227.0081

TREFON, T. 2009. Public service provision in a failed state: looking beyond predation in the democratic republic of congo. Review of African political economy 36(119): 9-21. Https://Doi.Org/10.1080/03056240902863587 
TROUVÉ, J. 1995. Les politiques publiques en matière de forêts dans l'Afrique francophone subsaharienne, 46pp.

TSAYEM, D.M., SUFO-KANKEU, R., and SONWA, D.J. 2020. Analysing the narrative and promises of "avoided deforestation" implementation in Central Africa. International Forestry Review 22(2): 257-268. Https://Doi.Org/ $10.1505 / 146554820829403469$

VIARD-CRÉTAT, A. 2015. La déforestation évitée socioanthropologie d' un nouvel «or vert» entre lutte contre le changement climatique et aide au développement, du laboratoire guyanais à l'expertise forestière au cameroun. école de hautes études en sciences sociales, thèse de doctorat, 742pp.

WEBER, M. 1978. Economy and society. University of California press.

WINTERBOTTOM, R. 1990. Takings stock: The tropical forestry acion plan after five years. In Wold Resources Institute (Issue January), 60pp.
WORLD BANK. 1989. Sub-saharan africa: From cris to sustainable growth. A long term perespective study, 322pp.

WORLD BANK. 1994a. A strategy for the forest sector in sub-saharan africa. World Bank Technical Paper No. Wtp 251. Africa technical department Series Washington, D.C: World Bank Group Http://Documents.Worldbank.Org/ Curated/En/802821468742853336/A-Strategy-For-TheForest-Sector-In-Sub-Saharan-Africa.

WORLD BANK. 1994b. Governance: the world bank's experience. In World Bank. Http://Documents.Worldbank.Org/ Curated/En/711471468765285964/Pdf/Multi0page.Pdf

WORLD BANK. 2007. RD Congo: Les peuples autochtones contestent la politique forestière de la banque mondiale, $4 \mathrm{pp}$.

WWF. 2012. L'analyse de l'expérience de la réforme du secteur forestier pour tirer des leçons nécessaires et contribuer au processus de la réforme du secteur minier en RDC, 125pp. 